\title{
METODE PEMBELAJARAN TUTOR SEBAYA SEBAGAI UPAYA MENINGKATKAN HASIL BELAJAR SISWA
}

\author{
Angela Merici Fina Indriani \\ Siti Mutmainnah \\ SMK Negeri 1 Pamekasan \\ xienq86@gmail.com
}

\begin{abstract}
The purpose of this research is to apply cooperative learning model with peer tutoring method to improve learning achievement. This research is a classroom action research in two cycles. The lesson of first cycle is adjusting journal, and the lesson of second cycle are worksheet and financial statements. The subject of this research were student in XI Keuangan 1 in SMK Negeri 1 Pamekasan. The result showed that application of peer tutoring method can improve student achievement to prepare financial statement on the trading companies at financial subject in XI Keuangan 1 SMK Negeri 1 Pamekasan.
\end{abstract}

Keywords: peer tutoring method, classroom action research, learning achievement

\begin{abstract}
Abstrak: Tujuan penelitian ini adalah untuk mengetahui penerapan model pembelajaran kooperatif dengan metode tutor sebaya (Peer Tutoring) sebagai upaya meningkatkan hasil belajar siswa. Penelitian ini merupakan penelitian tindakan kelas yang dilakukan dalam dua siklus, siklus I dengan materi jurnal penyesuaian dan siklus II neraca lajur dan laporan keuangan. Subyek penelitian ini adalah siswa kelas XI Keuangan 1 SMK Negeri 1 Pamekasan. Hasil penelitian menunjukkan bahwa penerapan metode pembelajaran tutor sebaya (peer tutoring) dapat meningkatkan hasil belajar siswa pada mata diklat menyusun laporan keuangan pada siswa kelas XI Keuangan 1 SMK Negeri 1 Pamekasan.
\end{abstract}

Kata Kunci: metode pembelajaran tutor sebaya, penelitian tindakan kelas, hasil belajar

Proses belajar mengajar merupakan satu rangkaian yang saling terkait dan tidak dapat dipisahkan. Kegiatan pembelajaran yang dilakukan guru merupakan salah satu penentu keberhasilan proses belajar siswa. Siswa akan belajar dengan lebih baik dan bermakna apabila kegiatan pembelajaran yang dipilih oleh guru relevan dan mendukung aktivitas belajar siswa. Kegiatan belajar mengajar sudah selayaknya berfokus pada siswa yang belajar (student oriented) bukan peran guru yang dominan. Hal ini perlu sama-sama disadari oleh kedua belah pihak baik guru maupun siswa, guru hanya bertindak sebagai fasilitator dalam kegiatan belajar mengajar yang bertugas 
mambuat desain pembelajaran sedangkan siswa merupakan subjek belajar yang harus benar-benar aktif dan sungguh-sungguh mengikuti kegiatan belajar mengajar.

Kegiatan belajar mengajar harus melibatkan tiga unsur yakni antara pengajar, peserta didik dan realitas dunia (Suyatno, 2009:5). Praktek nyata yang terjadi selama ini, ketiga hal tersebut kurang mendapatkan perhatian yang serius. Guru hanya menikmati tugasnya mengajar, menyiapkan materi pembelajaran, menjelaskan materi dengan metode ceramah dan sesekali tanya jawab kemudian memberikan soal latihan untuk dikerjakan siswa. Guru merasa penjelasannya sudah bisa diterima siswa ketika tidak ada pertanyaan yang diajukan oleh siswa dan terkadang guru merasa aman dengan hal tersebut. Guru lebih sering mengabaikan faktor perbedaan latar belakang antara siswa dan guru juga lingkungan dalam mendesain kegiatan belajar mengajar yang akan dilakukan di kelas. Kegiatan belajar mengajar yang ada saat ini mengakibatkan rasa (kepekaan) siswa dalam mencerna apa yang dipikirkan oleh otak dengan apa yang direfleksikan dalam sanubari dan perilaku-perilaku keseharian mereka sebagai siswa semakin senjang. Siswa mengetahui banyak tentang pengetahuan yang diajarkan melalui berbagai mata pelajaran yang ada dalam kurikulum sekolah, namun mereka bingung bagaimana mengimplementasikannya dalam kehidupan nyata (Fathul Mujib, 2012:48-49).

Salah satu perbedaan latar belakang antara guru dan siswa yang dianggap menjadi penyebab kurang maksimalnya hasil belajar siswa adalah perbedaan bahasa ibu yang digunakan oleh guru dan siswa. Perbedaan bahasa ibu ini menyebabkan siswa kurang bisa menangkap penjelasan materi dari guru secara maksimal, walaupun seharusnya bahasa baku yang digunakan dalam kegiatan pembelajaran adalah bahasa indonesia, pada kenyataannya masih banyak siswa yang lebih nyaman jika dijelaskan dengan bahasa ibu mereka, yaitu bahasa madura. Sedangkan bahasa ibu dari guru pengajar adalah bahasa jawa. Untuk mengatasi perbedaan tersebut, maka guru berusaha mencari solusi dengan menerapkan pembelajaran kooperatif yang mengedepankan kerja sama antar siswa dalam proses belajar mengajar. Salah satu metode dalam pembelajaran kooperatif adalah metode tutor sebaya (peer tutoring).

Inti dari metode tutor sebaya (peer tutoring) adalah guru memberdayakan siswa yang mempunyai daya serap tinggi terhadap materi yang dijelaskan guru untuk membantu siswa lain yang daya serapnya rendah. Siswa yang berperan sebagai tutor terlebih dahulu dibekali oleh materi yang akan dibahas dalam kegiatan belajar mengajar yaitu jurnal penyesuaian, neraca lajur dan menyusun laporan keuangan. Pembekalan ini dapat dilakukan di dalam maupun di luar jam pelajaran. Siswa yang berperan sebagai tutor bertugas membantu temannya yang mengalami kesulitan melalui proses diskusi setelah mendapatkan pembekalan dari guru pengajar. Peran guru pada proses ini adalah mengawasi kelancaran pelaksanaan metode dengan mengamati, mencatat perkembangan proses, memberikan pengarahan serta evaluasi proses untuk selanjutnya digunakan 
sebagai dasar perbaikan pada proses selanjutnya. Pembelajaran ini mempunyai kelebihan ganda yaitu siswa yang belum memahami materi mendapat bantuan lebih efektif untuk memahaminya sedangkan bagi tutor merupakan kesempatan untuk mengembangkan diri.

Penelitian sejenis yang sudah pernah dilakukan berkaitan dengan penerapan pembelajaran kooperatif dengan metode tutor sebaya (peer tutoring) menunjukkan bahwa penerapan metode pembelajaran tutor sebaya pada kelas X Akuntansi dengan materi menyusun laporan keuangan dapat meningkatkan hasil belajar siswa. Penelitian yang dilakukan oleh Maryani (2010) lebih lanjut menjelaskan bahwa indikator peningkatan hasil belajar siswa dapat dilihat dari meningkatnya antusisme dan semangat siswa dalam kegiatan belajar mengajar, meningkatnya pemahaman siswa terhadap materi pelajaran serta meningkatnya kecakapan sosial siswa sebagai hasil dari proses kerja sama dan diskusi selama kegiatan belajar mengajar.

Pembelajaran kooperatif dengan metode tutor sebaya (peer tutoring) selama ini belum pernah diterapkan oleh guru pengajar. Kegiatan belajar mengajar yang diterapkan selama ini masih menggunakan metode konvensional dimana guru menerangkan dengan metode ceramah, memberikan tugas dan tanya jawab. Proses belajar tersebut tidak memberikan hasil yang maksimal karena pada kenyataannya siswa kelas XI Keuangan 1 SMK Negeri 1 Pamekasan kurang memahami materi dan konsep yang diterangkan oleh guru. Hal ini disebabkan oleh perbedaan latar belakang dan bahasa ibu antara guru dan siswa disamping juga pemilihan metode pembelajaran yang kurang tepat dan relevan dengan materi dan perkembangan siswa. Berdasarkan data yang dihimpun di lapangan, penelitian ini bertujuan untuk mengukur efektifitas pembelajaran kooperatif dengan metode tutor sebaya (peer tutoring) pada mata diklat menyusun laporan keuangan di SMK Negeri 1 Pamekasan.

Menurut Susilowati (2009:3-28) tutor sebaya adalah seorang murid membantu belajar murid lainnya dengan tingkat kelas yang sama. Metode tutor sebaya dilakukan dengan cara memberdayakan kemampuan siswa yang memiliki daya serap tinggi, siswa tersebut mengajarkan materi kepada teman-temannya yang belum paham sehingga memenuhi ketuntasan belajar semuanya. Jadi, diharapkan dengan adanya tutor sebaya, peserta didik yang kurang aktif menjadi aktif. Dalam kelas tutor sebaya, tugas guru adalah sebagai fasilitator, mediator, motivator dan evaluator. Sedangkan tugas tutor adalah membantu temannya yang mengalami kesulitan belajar, karena hubungan antara teman sebaya umumnya lebih dekat dibandingkan hubungan guru - siswa (Abu Ahmadi dan Widodo Supriyono, 2004:184).

Langkah-langkah pelaksanaan pembelajaran menggunakan metode tutor sebaya adalah (1) memilih tutor dengan syarat termasuk dalam peringkat 10 terbaik berdasarkan nilai rapor atau nilai evaluasi sebelumnya dan dapat menguasai materi, (2) membagi siswa menjadi beberapa kelompok berdasarkan tingkat kecerdasan siswa (ada yang pandai, sedang dan kurang), (3) tutor memberikan 
bimbingan dan membahas soal yang berhubungan dengan materi yang diajarkan, (4) mengisi lembar observasi selama proses pembelajaran berlangsung, dan (5) melaksanakan evaluasi belajar secara individu.

Syarat - syarat yang harus dipenuhi untuk menjadi tutor sebaya antara lain, berprestasi baik, dapat diterima atau disetujui oleh siswa yang mendapat bantuan sehingga siswa leluasa bertanya, dapat menerangkan dengan jelas bahan pengajaran yang dibutuhkan oleh siswa, berkepribadian ramah, lancar berbicara, luwes dalam bergaul, tidak sombong dan memiliki jiwa penolong serta memiliki daya kreatifitas yang cukup untuk membimbing temannya (Suharsimi Arikunto, 1988:6263). Beberapa kiat yang bisa dilaksanakan untuk menjadi tutor yang baik yaitu mau terus belajar dan memperluas wawasan, rajin mencari informasi tambahan, menyisipkan humor dalam memberikan materi, kreatif mencari alat bantu serta pandai menghidupkan suasana (Muladi Wibowo, 2004:9).

Setiap metode pembelajaran yang diterapkan di kelas tidak sepenuhnya sempurna, selalu ada kelebihan dan kekurangan pada setiap metode pembelajaran terebut. Menurut Suharsimi Arikunto (1988:64) kelebihan metode tutor sebaya antara lain, menyampaikan informasi lebih mudah sebab bahasanya sama, kesulitan lebih terbuka, suasana yang rileks menghilangkan rasa takut, mempererat persahabatan, ada perhatian terhadap perbedaan karaktersitik, konsep mudah dipahami, serta siswa tertarik untuk bertanggung jawab dan mengembangkan kreatifitas. Sedangkan kelemahan metode tutor sebaya yaitu, kurang serius dalam belajar, jika siswa punya masalah dengan tutor ia akan malu bertanya, sulit menentukan tutor yang tepat, tidak semua siswa pandai dapat jadi tutor.

Belajar merupakan kegiatan yang kompleks. Gagne dalam Dimyati dan Mujiono (2002:9) mendefinisikan hasil belajar sebagai kapabilitas (kemampuan). Siswa akan memiliki keterampilan, pengetahuan, sikap, dan nilai setelah melakukan kegiatan belajar. Hasil belajar dapat berupa perkembangan atau perubahan kemampuan fisik, intelektual, sosial dan moral. Hasil dari proses belajar mengajar mencakup tiga ranah yaitu ranah kognitif (pemahaman terhadap materi atau bahan pembelajaran yang telah diberikan), ranah afektif (sikap, nilai, penghayatan) dan ranah psikomotorik (keterampilan, kemampuan bertindak, pengamalan).

Hasil belajar didefinisikan sebagai kapabilitas / kemampuan(Gagne dalam Dimyati \& Mudjiono, 2002:9). Siswa akan memiliki keterampilan, pengetahuan, sikap dan nilai setelah melakukan kegiatan belajar. Hasil belajar dapat berupa perkembangan atau perubahan kemampuan fisik, intelektual, sosial dan moral. Hasil dari proses belajar mengajar mencakup tiga ranah yaitu kognitif, afektif dan psikomototik. Ranah kognitif adalah ranah yang mencakup kegiatan mental (otak). Ranah kognitif meliputi enam jenjang antara lain pengetahuan, pemahaman, penerapan, analisis, sintesis dan evaluasi (Bloom 1956 dalam Sudiono, 2006:49-52). Ranah afektif adalah ranah yang berkaitan dengan sikap dan nilai. Ranah afektif mencakup lima jenjang antara lain 
penerimaan, menanggapi, menilai, mengorganisasikan dan karakterisasi / keterpaduan dengan suatu nilai atau kompleks nilai (Krathwohl 1974 dalam Sudiono, 2006: 54-56). Sedangkan ranah psikomotorik adalah ranah yang berkaitan dengan keterampilan atau kemampuan bertindak setelah siswa menerima pengalaman belajar tertentu. Hasil belajar psikomotor tampak dalam bentuk keterampilan dan kemampuan bertindak individu. Hasil belajar psikomotor sebenarnya merupakan kelanjutan dari hasil belajar kognitif dan afektif. Hasil belajar kognitif dan afektif akan menjadi hasil belajar psikomotor apabila peserta didik telah menunjukkan perilaku atau perbuatan tertentu sesuai dengan makna yang terkandung dalam ranah kognitif dan afektif (Simson 1956 dalam Sudiono, 2006: 57-58).

Hasil belajar yang dicapai siswa tergantung dari proses belajar yang yang terjadi dalam diri siswa tersebut. Hasil belajar akuntansi yang dicapai siswa merupakan hasil belajar secara keseluruhan yang dikonversikan dalam bentuk nilai yang meliputi kemampuan kognitif (pengetahuan), afektif (sikap) serta psikomotorik (keterampilan). Hasil belajar dapat dijadikan sebagai indikator kualitas dan kuantitas pengetahuan yang telah dikuasi oleh siswa, selain itu juga dapat digunakan untuk mengukur keberhasilan proses belajar mengajar yang telah dilakukan oleh guru. Guru dapat menilai dan mengukur kemampuannya dalam proses belajar mengajar yang pada akhirnya dapat dijadikan bahan evaluasi dan perbaikan pada proses belajar mengajar berikutnya.

\section{METODE}

Penelitian dilaksanakan di tempat peneliti mengajar, yaitu SMK Negeri 1 Pamekasan. Waktu penelitian adalah dari bulan Februari 2014 sampai bulan Mei 2014. Subjek penelitian adalah XI Keuangan 1 dengan jumlah 33 siswa. Alasan pemilihan tempat dan subjek penelitian adalah SMK Negeri 1 Pamekasan adalah sekolah dan kelas tempat peneliti melaksanakan tugas mengajar sehari-hari.

Penelitian yang dilaksanakan adalah penelitian tindakan kelas ( PTK). Penelitian tindakan kelas dipilih karena bersifat praktis, menyangkut kegiatan yang dipraktekkan guru dalam melaksanakan tugas mengajarnya. Menurut Rustam dan Mundilarto (2004:1) "penelitian tindakan kelas (PTK) adalah sebuah penelitian yang dilakukan oleh guru di kelasnya sendiri dengan jalan merancang, melaksanakan dan merefleksikan tindakan secara kolaboratif dan partisipatif dengan tujuan untuk memperbaiki kinerjanya sebagai guru sehingga hasil belajar siswa dapat meningkat" 
Secara umum alur pelaksanaan tindakan dalam penelitian tindakan ini dapat digambarkan sebagai berikut:

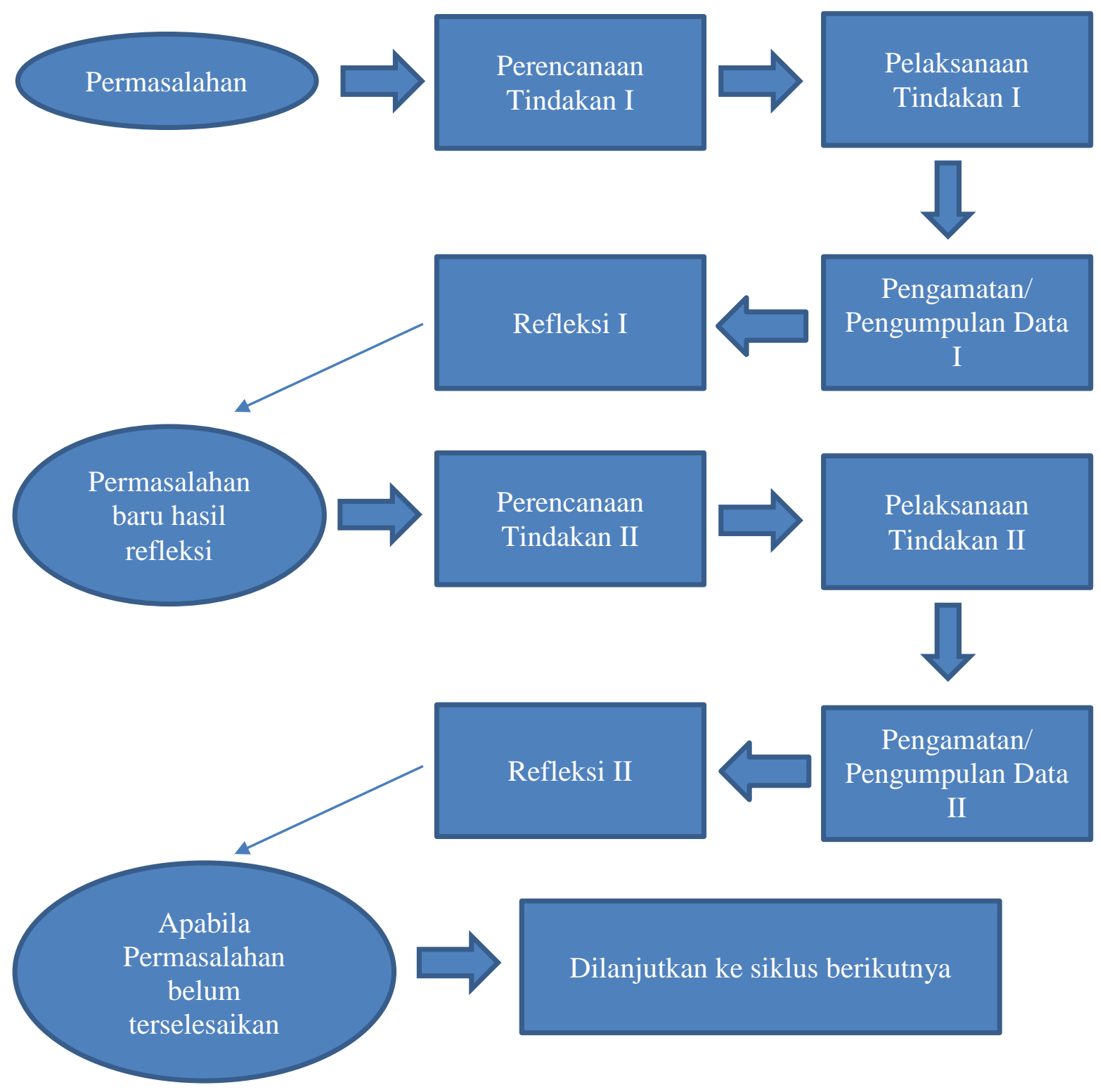

\section{Gambar 1. Siklus Penelitian Tindakan}

(Suhardjono dalam Suharsimi Arikunto, Suhardjono dan Sapardi, 2007: 74)

Permasalahan yang terjadi adalah selama proses pembelajaran pada semester 1, siswa XI

Keuangan 1 kurang bersemangat untuk memperoleh ilmu yang akhirnya berdampak pada nilai yang buruk dengan nilai rata - rata kelas 54. Permasalahan masih berlanjut hingga semester 2 awal yang ditunjukkan dengan hasil ulangan harian pertama yang hanya memperoleh nilai rata-rata kelas 46 dan enam siswa dengan nilai di atas 75 .

Perencanaan tindakan dilakukan setelah melihat permasalahan tersebut. Peneliti membuat angket mengenai alasan siswa kurang memahami pelajaran akuntansi. Dari angket diketahui bahwa mereka kurang memahami bahasa yang dipakai dalam proses pembelajaran karena kebanyakan siswa berasal dari daerah pinggiran yang bahasa sehari-hari yang mereka gunakan adalah bahasa 
daerah. Untuk itu, guru dan peneliti mencari metode pembelajaran yang bisa mengatasi permasalahan tersebut. Metode tutor sebaya dianggap sebagai metode yang tepat, karena siswa yang lebih pandai dapat menjelaskan materi dengan bahasa daerah mereka sehingga siswa yang lain menjadi lebih paham. Setelah metode pengajaran terpilih, selanjutnya guru dan peneliti membuat RPP dengan model pembelajaran tutor sebaya, menyusun lembar observasi agar dapat mengamati kondisi pembelajaran siswa, mempersiapkan materi yang akan diberikan, mempersiapkan lembar kerja sebagai bahan diskusi kelompok, menyusun instrumen evaluasi pembelajaran, yaitu soal ulangan,

Pelaksanaan tindakan dilakukan sesuai dengan rencana yang telah disusun, yaitu pembelajaran dengan menggunakan metode tutor sebaya. Metode tutor sebaya merupakan metode yang dilakukan dengan cara memperdayakan kemampuan siswa yang memiliki daya serap tinggi, siswa tersebut mengajarkan materi atau latihan kepada temantemannya yang belum paham. Menurut Soeprodjo, dkk seperti yang dikutip dari http://zaifbio.wordpress.com/2013/09/13/metode-tutor-sebaya/ (2013), pemakaian tutor dari teman mereka memungkinkan siswa tidak merasa enggan untuk bertanya, dengan adanya tutor dapat memberikan keringanan pada guru dalam memberikan contoh soal atau latihan. Peran guru adalah mengawasi kelancaran pelaksanaan metode ini dengan memberi pengarahan dan lain-lain.

Pengamatan dan pengumpulan data dilakukan bersamaan saat pelaksanaan proses pembelajaran. Peneliti melakukan pengamatan dan mencatat semua hal yang terjadi selama proses pembelajaran. Pengumpulan data ini menggunakan lembar observasi yang telah disusun. Data yang dikumpulkan berupa data obervasi, hasil evaluasi, nilai tugas dan lain-lain.

Refleksi dimaksudkan untuk mengkaji secara menyeluruh tindakan yang telah dilakukan. Data yang telah terkumpul dievaluasi untuk menyempurnakan tindakan berikutnya. Jika permasalahan masih belum selesai, maka perlu pengkajian ulang untuk siklus berikutnya yang meliputi perencanaan ulang, pelaksanaan ulang, pengamatan ulang dan refleksi ulang sehingga permasalahan dapat teratasi. Indikator keberhasilan penelitian adalah jika ketuntasan hasil belajar (standar nilai 75) mencapai 80\%.

\section{HASIL DAN PEMBAHASAN}

Metode pembelajaran dalam penelitian ini adalah metode tutor sebaya. Langkah-langkah pelaksanaan pembelajaran menggunakan metode tutor sebaya adalah (1) memilih tutor dengan syarat termasuk dalam peringkat 10 terbaik berdasarkan nilai rapor atau nilai evaluasi sebelumnya dan dapat menguasai materi, (2) membagi siswa menjadi beberapa kelompok berdasarkan tingkat kecerdasan siswa (ada yang pandai, sedang dan kurang), (3) tutor memberikan bimbingan dan 
membahas soal yang berhubungan dengan materi yang diajarkan, (4) mengisi lembar observasi selama proses pembelajaran berlangsung, dan (5) melaksanakan evaluasi belajar secara individu.

Langkah awal metode tutor sebaya adalah memilih tutor. Pemilihan tutor disiapkan mulai dari perencanaan tindakan yang dilakukan bulan Februari sampai Maret 2014. Selama bulan Februari - Maret, peneliti melakukan observasi awal untuk menentukan siswa yang akan menjadi tutor. Tutor dipilih berdasarkan nilai semester 1, tingkah laku keseharian selama observasi dan ulangan harian pertama semester 2. Enam siswa yang memiliki kemampuan lebih dipilih menjadi ketua kelompok sekaligus tutor untuk masing - masing kelompok. Pelaksanaan tindakan dan pengamatan atau pengumpulan data dilaksanakan dalam tiga pertemuan.

Pertemuan pertama merupakan penerapan untuk langkah yang kedua dalam tutor sebaya yaitu membagi siswa menjadi beberapa kelompok berdasarkan tingkat kecerdasannya. Pertemuan pertama pada siklus pertama ini dilaksanakan tanggal 21 April 2014. Pada pertemuan pertama ini guru memberitahu siswa metode yang akan dilaksanakan selama bulan April - Mei 2014 yaitu metode tutor sebaya. Guru menjelaskan bahwa kelas akan dibagi menjadi enam kelompok secara heterogen dengan rincian tiga kelompok akan berjumlah lima orang, sedangkan tiga kelompok lainnya berjumlah enam orang. Hal ini dikarenakan jumlah siswa XI Keuangan 1 adalah 33 siswa.

Ketua dan wakil ketua kelompok telah ditentukan oleh guru, dan untuk anggota kelompok dilakukan bersama-sama antara guru dan ketua serta wakil ketua kelompok. Hal ini dilakukan agar ketua kelompok merasa nyaman dengan anggota kelompoknya, dan kemampuan anggota yang sedang dan kurang dapat terbagi rata pada masing-masing kelompok. Pertemuan pertama diisi dengan pembagian anggota kelompok dan pembagian materi dan lembar kerja pada masing masing kelompok. Materi yang diberikan adalah jurnal penyesuaian. Ketua kelompok dipanggil untuk menerima penjelasan singkat tentang materi jurnal penyesuaian dan memberi kesempatan untuk bertanya materi yang belum dimengerti. Ketua kelompok menyatakan bahwa mereka telah paham dan sanggup menjadi tutor untuk teman sekelompoknya. Pertemuan diakhiri dengan menjelaskan rencana untuk pertemuan selanjutnya.

Langkah yang ketiga dan keempat yaitu tutor memberikan bimbingan dan membahas soal dan guru mengisi lembar observasi dilaksanakan pada pertemuan kedua, 26 April 2014. Pada pertemuan ini guru menyuruh siswa untuk duduk dengan kelompoknya dalam posisi siap berdiskusi. Lembar kerja yang telah dibagikan didiskusikan dan dikerjakan dalam kelompok belajarnya masing-masing. Selama siswa berdiskusi dan mengerjakan tugas, guru dan peneliti berkeliling dan mengamati jalannya diskusi sambil mengisi lembar observasi, yaitu observasi aktivitas siswa, observasi kinerja tutor sebaya, dan observasi keterlaksanaan pembelajaran.

Aspek yang dinilai untuk kinerja tutor sebaya adalah (1) melakukan persiapan sebelum pembelajaran; (2) menguasai materi yang akan diajarkan; (3) berbicara dengan baik dan benar; (4) 
bisa bekerjasama dan melibatkan semua siswa dalam kelompoknya; (5) memberikan pertanyaan pada anggota yang diajari; (6) bisa mengatur waktu dengan cermat; (7) duduk dalam posisi berdiskusi; dan (8) mempunyai sikap yang baik, sabar dan penuh percaya diri. Hasil observasi untuk kinerja tutor sebaya pada siklus pertama ini yaitu ada dua tutor yang melakukan persiapan sebelum pembelajaran, yaitu sesudah pertemuan pertama mereka bertanya materi yang masih belum dipahami, sedangkan empat tutor yang lain terlihat belum melakukan persiapan karena mereka baru bertanya pada tengah-tengah diskusi pertemuan kedua. Semua tutor belum menguasai semua materi jurnal penyesuaian, mereka masih bingung membedakan penyesuaian untuk beban dibayar dimuka yang menggunakan pendekatan neraca dan pendekatan laba rugi, perhitungan jangka waktu bunga, dan penyusutan dengan metode saldo menurun. Bahasa yang tutor gunakan adalah bahasa daerah Madura karena mereka lebih nyaman dengan bahasa sehari-hari mereka. Empat orang tutor bisa bekerjasama dengan anggota kelompoknya sedangkan dua tutor yang lain masih belum melibatkan semua anggotanya dan kecenderungan hanya menjelaskan pada satu orang saja sehingga anggota yang lain berbicara antara satu dengan yang lain. Semua tutor tidak memberikan pertanyaan lain kepada anggotanya selain soal yang telah dibagikan oleh guru. Tutor juga belum bisa mengatur waktu dengan cermat yang terlihat pada saat kelompok lain maju dan mengerjakan soal, mereka masih sibuk mengerjakan soalnya. Ada satu tutor yang menghadap guru mengeluh tentang salah satu anggota kelompoknya yang tidak mau memperhatikan, tutor yang lain juga mengeluh salah satu anggotanya tidak paham sama sekali dengan pelajaran akuntansi. Hasil observasi aktivitas siswa adalah 76\% siswa menunjukkan minat mendengarkan tutornya masing-masing, 54\% memberi respon dengan bertanya pada tutornya, dan secara keseluruhan $67 \%$ siswa mampu bekerjasama dengan baik dalam kelompoknya.

Diskusi dilakukan selama empat jam pelajaran dengan berbagi aktivitas, ada yang serius mendengarkan tutornya, ada yang setengah mendengarkan tutornya dan ada juga yang tidak mendengarkan tutornya. Ketika guru mengumumkan bahwa yang akan menyampaikan dan membahas soal adalah anggota kelompok yang akan dipilih secara acak, mereka langsung serius mendengarkan tutor dan mengerjakan soal yang telah diberikan.

Sisa dua jam pelajaran diisi dengan pembahasan soal oleh masing-masing kelompok secara bergantian. Guru memilih anggota kelompok secara acak untuk maju mengerjakan soal dan menjelaskan pembahasannya pada kelompok yang lain. Rata-rata siswa yang ditunjuk bisa mengerjakan tapi masih kesulitan untuk menjelaskan pada kelompok yang lain, ada juga yang terlihat menghafal jawabannya. Pertemuan kedua ditutup dengan evaluasi pembelajaran pada hari itu dan mengingatkan tugas dan tanggung jawab tutor dan anggota kelompok serta pengumuman pelaksanaan evaluasi secara individu pada pertemuan berikutnya dengan materi jurnal penyesuaian. 
Pertemuan ketiga dilaksanakan tanggal 28 April 2014 dengan kegiatan pembelajaran yaitu evaluasi. Kelas dibagi menjadi dua kelompok sesuai no absen, yaitu absen ganjil dan absen genap. Absen ganjil melaksanakan evaluasi lebih dahulu, setelah pergantian jam pelajaran giliran absen genap yang melaksanakan evaluasi. Hal ini dilakukan untuk mempermudah pengawasan sehingga kesempatan siswa untuk bekerjasama menjadi kecil. Hasil evaluasi menunjukkan bahwa 14 siswa $(42,4 \%)$ memperoleh nilai diatas 75 , dengan nilai tertinggi 100 , nilai terendah 8 dan rata-rata kelas adalah 60 .

Berdasarkan observasi dan hasil evaluasi tersebut, tindakan refleksi yang dapat dilakukan antara lain: (1) Guru memberikan penjelasan ulang tentang pembelajaran dengan metode tutor sebaya dan tujuannya sehingga siswa lebih memahami arti kerjasama dan tanggung jawab dalam kelompok, (2) Guru menanyakan kesulitan yang dihadapi tutor dan memberi pengarahan pada tutor untuk mengatasi kesulitan tersebut, (3) Guru melakukan pendekatan pada siswa yang masih acuh dalam kegiatan pembelajaran, (4) Guru memberikan penghargaan kepada siswa yang dapat bekerjasama dan mengerjakan tugas dengan baik dengan tujuan untuk memacu semangat anggota kelompok yang lain, dan (5) Guru perlu memberikan waktu yang lebih banyak, karena waktu delapan jam pelajaran yang dibagi menjadi dua pertemuan masih kurang untuk menjelaskan materi.

Dari hasil refleksi siklus pertama, dibuat rencana tindakan untuk siklus kedua. Perencanaan tindakan dilakukan dari 28 April hingga 2 Mei 2014 dengan hasil bahwa jumlah pertemuan akan diperbanyak yaitu menjadi 3 pertemuan untuk pembahasan materi dan 2 pertemuan untuk evaluasi. Pertemuan pertama pada siklus kedua sebagai pelaksanaan tindakan dilaksanakan tanggal 3 Mei 2014 yang dimulai dengan doa, mengecek kehadiran siswa dan menciptakan situasi yang kondusif untuk kegiatan pembelajaran. Evaluasi hasil belajar sebelumnya diumumkan dan guru memberikan penghargaan kepada siswa dengan nilai tertinggi dan kepada kelompok dengan nilai rata-rata tertinggi. Setelah hasil belajar diumumkan, guru membahas kembali soal evaluasi dan mengulang kembali penjelasan penyesuaian untuk beban dibayar dimuka yang menggunakan pendekatan neraca dan pendekatan laba rugi.

Siklus kedua membahas materi neraca lajur dan laporan keuangan. Pada pertemuan pertama ini guru menjelaskan tentang neraca lajur dan laporan keuangan, yaitu laporan laba/rugi, laporan ekuitas, laporan posisi keuangan, dan laporan arus kas. Materi laporan arus kas adalah materi baru bagi siswa, sehingga guru mengulang kembali penjelasan tentang laporan arus kas. Guru memberi kesempatan kepada siswa untuk memahami materi dan memberi kesempatan untuk tanya jawab. Rata-rata yang bertanya adalah siswa yang menjadi tutor dan wakil ketua kelompok. Setelah tanya jawab, guru meminta siswa untuk duduk berkelompok seperti pada pertemuan sebelumnya. Tutor dipanggil kedepan untuk menerima penjelasan ulang mengenai konsep, perintah, materi dan petunjuk arahan supaya tutor dapat membantu memberikan penjelasan kepada temannya dalam 
kelompok, sedangkan siswa yang lain membaca materi yang telah dibagikan. Setelah tanya jawab antara tutor dan guru, guru membagikan lembar kerja untuk dibahas pada masing-masing kelompoknya. Pertemuan pertama ditutup dengan menyampaikan rencana kegiatan berikutnya dan memberikan motivasi kepada siswa bahwa guru akan memberikan penghargaan pada kelompok dengan rata-rata terbaik dan akan memberi hukuman pada kelompok terburuk. Motivasi guru ini membuat siswa menjadi lebih bersemangat, terutama kelompok yang sudah mendapatkan penghargaan sebelumnya.

Pertemuan kedua dan ketiga dilaksanakan tanggal 5 dan 10 Mei 2014 dengan kegiatan melanjutkan pembahasan materi dan pengerjaan soal pada kelompok masing-masing. Pada siklus kedua ini terlihat peningkatan minat siswa untuk mendengarkan penjelasan tutornya, yaitu menjadi $89 \%$, yang memberi respon bertanya menjadi 83\%, dan kerjasama dalam kelompok juga meningkat menjadi $86 \%$. Kinerja tutor juga menjadi lebih baik, semua tutor telah melibatkan semua siswa dalam kelompoknya untuk bekerjasama. Mereka juga telah melakukan persiapan sebelum pembelajaran dengan membuat ringkasan materi agar lebih dipahami oleh anggota kelompoknya masing-masing, dan mereka juga telah menguasai materi yang akan diajarkan yaitu neraca lajur dan laporan keuangan.

Pada pertemuan ketiga dilakukan pembahasan hasil diskusi kelompok yang dipilih secara acak dari anggota kelompok. Pembahasan ini juga berjalan lancar, siswa lebih percaya diri dalam menyampaikan hasil pekerjaannya dan mampu menjelaskan dengan baik kepada kelompok yang lain. Kelompok yang lainpun dengan tenang mendengarkan dan mengajukan pertanyaan kepada kelompok yang maju. Pertemuan ketiga ditutup dengan guru memberikan kesimpulan tentang materi neraca lajur dan laporan keuangan baik secara konsep maupun dengan latihan soal dari tugas yang sudah dibahas. Guru juga memberi pengumuman bahwa tanggal 12 Mei akan dilakukan evaluasi hasil belajar dengan materi jurnal penyesuaian dan neraca lajur, sedangkan evaluasi untuk materi laporan keuangan akan dilaksanakan tanggal 17 Mei 2014.

Hasil evaluasi pertama dengan materi jurnal penyesuaian dan neraca lajur menunjukkan hasil 19 siswa (58\%) dari 33 siswa mendapat nilai di atas 75 dengan nilai tertinggi 100, nilai terendah 17 , dan rata-rata kelas adalah 75 . Hasil evaluasi kedua dengan materi laporan keuangan menunjukkan peningkatan yaitu 27 siswa (82\%) dari 33 siswa mendapat hasil di atas 75 dengan nilai tertinggi 100 , nilai terendah 22 , dan rata-rata kelas 80 .

Hasil observasi dan hasil evaluasi menjadi dasar refleksi untuk siklus kedua, yaitu (1) guru lebih kreatif dalam menciptakan suasana pembelajaran yang kondusif sesuai kondisi siswa; (2) guru perlu memberikan motivasi berupa penghargaan kepada siswa dan kelompok terbaik; (3) hasil evaluasi siklus kedua menunjukkan bahwa $82 \%$ siswa telah mencapai nilai di atas 75 yang 
menunjukkan bahwa indikator keberhasilan, yaitu jika ketuntasan hasil belajar (standar nilai 75) mencapai $80 \%$ telah terlampaui sehingga PTK dapat diselesaikan.

\section{SIMPULAN}

Penelitian Tindakan Kelas (PTK) di kelas XI Keuangan 1 SMK Negeri 1 Pamekasan dengan metode tutor sebaya dilaksanakan dalam 2 siklus untuk mendapatkan hasil penelitian yang memenuhi indikator keberhasilan. Hasil penelitian menunjukkan bahwa terjadi peningkatan hasil belajar siswa, dari yang sebelumnya hanya 18\% siswa (6 siswa) yang mencapai menjadi nilai 75 , pada siklus pertama naik menjadi $42,4 \%$ siswa (14 siswa) yang mencapai dan melampaui nilai 75 , dan pada siklus kedua berhasil melampaui indikator keberhasilan penelitian, yaitu $82 \%$ siswa (27 siswa) memperoleh nilai di atas 75. Jadi, dapat disimpulkan bahwa metode pembelajaran tutor sebaya sebagai upaya meningkatkan hasil belajar siswa telah berhasil.

Penelitian ini memerlukan perbaikan dan penyempurnaan lebih lanjut. Beberarapa keterbatasan yang perlu diperhatikan antara lain, penelitian ini hanya dilaksanakan pada siswa kelas XI Keuangan 1 SMK Negeri 1 Pamekasan dengan materi jurnal penyesuaian, neraca lajur dan laporan keuangan sehingga perlu dilakukan penelitian pada subjek yang lain dengan materi yang berbeda.

\section{DAFTAR RUJUKAN}

Ahmadi, Abu \& Widodo Supriyono. 2004. Psikologi Belajar. Jakarta: Rineka Cipta.

Arikunto, Suharsimi. 1988. Pengelolaan Siswa \& Kelas (Sebuah Pendekatan Evaluatif). Jakarta: W. Rajawali.

Arikunto, Suharsimi, Suhardjono dan Supardi. 2007. Penelitian Tindakan Kelas. Jakarta: Penerbit Bumi Aksara.

Dimyati \& Mudjiono. 2002. Belajar \& Pembelajaran, Jakarta: Rineka Cipta.

Mujib, Fathul. 2012. Super Power Educating. Jogjakarta: Diva Press.

Rustam \& Mundilarto. 2004. Penelitian Tindakan Kelas. Jakarta: Direktorat Pembinaan Pendidikan

Tenaga Kependidikan dan Ketenagaan Perguruan Tinggi Direktorat Jenderal Pendidikan Tinggi Departemen Pendidikan Nasional.

Soeprodjo. 2013. Metode Tutor Sebaya, (Online), (http://zaifbio.wordpress.com/2013/09/13/metode-tutor-sebayal, diakses 26 Jan 2014) Sudiono, Anas. 2006. Pengantar Evaluasi Pendidikan, Jakarta: PT. Raja Grafindo Persada. Susilowati, dkk. 2009. Pembelajaran kelas rangkap. Direktorat Jenderal Pendidikan Tinggi Departemen Pendidikan Nasional.

Suyatno. 2009. Menjelajah Pembelajaran Inovatif. Sidoarjo: Masmedia Buana Pustaka. 